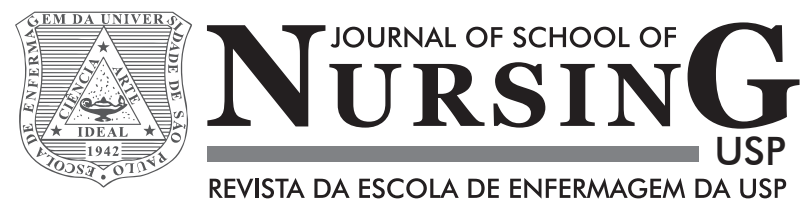

\title{
The Illness Experience: Palliative Care Given the impossibility of Healing*
}

\author{
A Experiência do Adoecer: Os Cuidados Paliativos diante da Impossibilidade da Cura \\ La experiencia de la enfermedad: Cuidados Paliativos Dada la imposibilidad de curación
}

Margarida Maria Florêncio Dantas ${ }^{1}$, Maria Cristina Lopes de Almeida Amazonas²

* Study extracted from the master's dissertation entitled: The Experience of Palliate care: A

view from the subject's own way before being ill. Presented at the Universidade Católica de Pernambuco in December 2014.

${ }^{1,2}$ Universidade Católica de Pernambuco, Recife, Pernambuco, Brazil.

\section{ABSTRACT}

This paper presents a reflection about being terminally ill and the various ways that the subject has at its disposal to deal with this event. The objective is to understand the experience of palliation for patients undergoing no therapeutic possibilities of cure. The methodology of this study has the instruments to semi-structured interview, the participant observation and the field diary, and the Descriptive Analysis of Foucault's inspiration how the narratives of the subjects were perceived. The Results of paper there was the possibility of looking at the experience of illness through the eyes of a subject position assumed by the very sick. As conclusion we have than when choosing palliative care, the terminally ill opts for a way to feel more comfortable and resists the impositions of the medical model of prolonging life.

\section{DESCRIPTORS}

Palliation, Sick, Finitude, Subject Position, Identity. 


\section{INTRODUCTION}

Being affected by a serious, chronic, progressive and degenerative illness can cause the subject to reflect about his/ her terminally process. And thinking about their own death, or even experience the finitude process, provokes different sensations and reactions, depending on how this event is experienced. At first, the feelings of surprise and shock before a diagnosis of poor prognosis is quite common, which in itself already brings grief over the possibility of dying. Regarding the cultural notion about death, Aries says:

It isn't easy to deal with death, but it awaits for all of us... not thinking about death does not slows it down or prevents it. Thinking about death can help us to accept it and realize that it is such an important and valuable experience as any other ${ }^{(1-20)}$.

However, thinking about death does not usually cause good feelings. Because it represents the end of a life, the end of the relationship made for life, and more, distance from loved ones and achievements made, the proximity of death may trigger unpleasant feelings. Dying, then, can be seen as bad and should not be desired, but avoided. The contradiction is that, for being rational, human beings are the only ones who have death as primordial certainty of life. Since childhood, the individual makes plans for life. Studying, working, marrying, having children, traveling, living alone, not getting married, having no children, but these are all plans, desires that the subject is not sure if he/ she will carry them out. However, he/she knows that he/ she will die ${ }^{(1)}$.

Despite all the denial and escape from death, this event is present uninterruptedly for life. We lose loved ones, whether through accident, disease, old age; we witness deaths of neighbors, acquaintances, public figures, both in a close manner or through news and/or informal conversations. And almost always, death is accompanied by grief, sadness, pain and, therefore, the need to distance ourselves from it ${ }^{(1)}$. This distance can be achieved in the case of a disease, from the futility to the therapeutic obstinacy, treatment aimed at curing the sick.

But the relationship with death, before being ill, was not always of avoidance, denial and fear. Dying has been experienced as a natural event, at a time when there was no knowledge about illness. This shows us that we must understand death from the effects related to the historical and cultural moment that we live and the society of which we belong. The concept of death, as well as the concept of illness, to name a few, are social constructions that are built from the knowledge of each society. Thus, ancient societies of the fifteenth century understood and explained the origin of death through stories and/or myths, different explanations of this topic came up in the centuries that followed. Thus, each society develops one or more funeral systems through which they can understand death in their personal and social aspects ${ }^{(1)}$.

Bearing in mind the fifteenth century perspective, death was experienced naturally, it happened at home, and the funeral and the last respects to the dead were also ex- perienced there. The cause of death was often illness, epidemics and infections that did not have diagnostic, because the medical clinic had not been invented yet. There were high rates of newborn deaths, also for lack of adequate assistance, which made the society of that century wait a year, sometimes two, for the child to "grow" and be baptized only then ${ }^{(1)}$.

Dying at that time had a direct relationship with no knowledge of medical practice and so there was not a negative view of the possibility of death. In the seventeenth century, with the increase of epidemics, Christianity began to worry about patients to avoid contamination. Thus, it was determined that patients should be referred to shelters that were referred as hospitals or "last resort", where people would die. The term hospital emerged from the hospice movement of religious connotation, these places admitted and cared for the sick or injured pilgrims, until they were recovered or died from it ${ }^{(1)}$.

In the late eighteenth century, medical practice began to settle. Diseases and infections were diagnosed and treated, allowing, from the twentieth century, death to be delayed ${ }^{(2)}$. However, medical clinic is limited in its curative action, especially to chronic, progressive, degenerative diseases that cause a painful, uncomfortable, undignified death. And on the inevitability of death and the need to care for the dying process, the palliative care, based on the hospice philosophy, was created.

Palliative care, then, "is the set of practical assistance to incurable patients, which aims to provide dignity and reduction of suffering" ${ }^{(3-48)}$. According to the World Health Organization (WHO), palliative care is "the active and total care of patients whose disease no longer responds to curative treatments. The goal is to achieve the best possible quality of life for patients and their families" ${ }^{(4-28)}$. Thus, palliative care shall be defined as a treatment of comfort.

Thus, pain relief is considered as the main principle of palliative care. For this reason, the concept Total Pain involves: the physical pain, the discomfort of the body; psychological pain felt by the loss of being healthy; social pain, represented by the loss of privacy, autonomy and social life; and spiritual pain, doubts about the after-death ${ }^{(5)}$.

As the focus of palliative care is not cure, palliative teams must have the ability to deal with the various moments of instability of the patient who experiences the threat of life due to an illness. Then, the team "offers a comprehensive care, special attention, enriched by the discussion that transcends the knowledge of each professional" ${ }^{(6-328)}$. This to allow a greater comfort from the discomfort felt by the sick subject, understanding that they are unique, personal and not transferable, that is, palliative care is a unique experience for every human being.

In this study, the objective was to understand the experience of palliation for ill subjects without therapeutic possibilities of cure. For this, we investigated: the construction of the meaning of the term palliation at the time they discovered the impossibility of cure; which led to the choice for patients undergoing palliative care as a way to care 
for themselves and style to exist; and the impacts of palliate care about the existence of these subjects.

\section{METHOD}

This study was inspired by a post-structuralism perspective. This paradigm considers language as a first instance that does not contain a hidden or absolute truth. Its representatives assume that the analysis of a particular phenomenon is only one possibility among many others to perceive it.

The analysis method of this study is the descriptive analysis based on Foucault's perspective, through the belief that the subject is crossed by discourse, rather, the subject is constructed through discourse. The construction of discourse is made from the manner in which the utterance is composed. So, there is not one unit in discourse, as the shape and type of utterance depends on which subject transmits this utterance, based on knowledge that the subject builds his/her perspective, and what context the speaking subject appears. Utterances, then, are related to discourse analysis, as it includes the subject of the statement by their language ${ }^{(7)}$.

Thus, utterances should be understood as fully historical, that is, they should be related to the rules of formation, not the typical specificities of historical knowledge. Utterances functions in network and, therefore, should not be understood in the sense of continuity, but in a circularity among other utterances, as they are in relation to each other. Describing these utterances relationship, however, means putting them in sets, which are called discursive formations.

This discursive formation is the correlation with the utterances. And in this way, Foucault defines discursive practices as the "set of anonymous and historical rules, always determined in time and space, which defined at a given time and a given social, economic, geographical, or linguistic areas, conditions to exercise the enunciation function"(7-136).

Regarding the perception of how the subjects ill deal with palliative care, we understand palliation as experience. And understanding a particular concept as experience implies "distancing ourselves, circulating familiar evidence, analyzing the theoretical and practical context to which it is associated"(7-9). That is, appropriating ourselves of the knowledge that composes this concept, the power systems that enable the realization of their practice and the ways in which the subject is recognized as a subject in palliation. Thus, the experience does not base the subject, it does not pre-exist to him/her, it operates in the possibilities of subjective process, from "... a correlation of a domain of knowledge, a type of normativity, one way of relationship within $(. .$.$) "(7-208).$

It is consistent to say that palliation as an experience is related to the principle of "man of desire", Foucault's expression, which means the particularity of each subject observed in the actions taken by him/her before his/her experiences. And even more, "the study of experience, that is, of practical reason, implies something distinct from a strictly epistemological study on the conceptualization of this reason" ${ }^{(8-102)}$. In this notion of "man of desire", it is possible to understand from the "practices of the self", replacing "a story of moral systems, made from barriers, by a history of ethical problems, made from the practices of the self" ${ }^{\prime(7-16)}$.

Subjects of discourse are crossed by their historicity, their culturalism, and society to which they belong to. We understand the subject constructed from these crossings, as they influence and act directly in their training. This makes the subject to produce and to be produced by discourses, that "build objects and a variety of subject positions"(9-112). And by subject position we understand and assume a position from possibilities updates, without the exhaustion of the possibilities of being. Thus:

$$
\begin{aligned}
& \text { Discourse, thus conceived, is not a manifestation, } \\
& \text { majestically developed, from a subject who thinks, } \\
& \text { knows, and says, instead, discourse is a set in which } \\
& \text { the dispersion of the subject and discontinuity with } \\
& \text { respect to oneself can be determined. It is an external } \\
& \text { space where a network of different places is develo- } \\
& \text { ped }{ }^{(10,61,62)} \text {. }
\end{aligned}
$$

Subjects who use the discourse should be perceived from their individuality and may, in their way, upgrade possibilities and undergo changes. "These constructions, in turn, provide certain modes-of-view of the world and certain modes-of-being in the world. Discourses offer subject positions, that, when taken, have implications for subjectivity and experience" ${ }^{\prime 9-112)}$. Taking the example of an ill subject, the medical discourse puts him/her in a patient position, someone who is "a passive recipient of specialized care in a healing path"(9-112).

However, this is not the only discourse that goes through the subject. Although challenged to take on this position-of-subject, there are a few more ways in which he/ she can invest. Discourses can describe a particular construction of being ill, at a certain historical moment, "but they do not explain what are the investment that individuals make in particular positions and the attachments they develop due to these positions (...) To occupy a specific position-of-subject (...) is not a matter of conscious personal choice" ${ }^{(11-59,60)}$. Discourses challenge us to take certain positions, but the investment that we do in them is private and is not restricted to conscious choices.

\section{A) PARticipants}

The participants were five patients who experienced the palliative treatment. They were hospitalized in a large hospital in the city of Recife/PE and chose this type of care after the finding of therapeutic impossibility of cure. The names of these subjects in the study are fictitious, to maintain their anonymity.

\section{B) INSTRUMENTS}

To produce the material for this study, the instruments used were the Narrative interview, the Participant Observation and the Field Diary. The choice of these instruments was due to the fact that we seek to understand the expe- 
rience of being in palliative care before a serious, chronic, progressive, degenerative illness, in which subjects were free to speak about their experience.

The Narrative Interview allows a freer contact on the topic between researcher and researched, without following a previous rigor and without losing the objective of the research. "There appears to be a need to tell on all forms of human life; storytelling is a basic form of human communication and, regardless of the performance of the stratified language, it is a universal capacity"(12-91). The Participant Observation is the entrance of the researcher in the field of research, in order to communicate to the subjects of the study and broaden the perception of their experiences during the observation ${ }^{(13)}$. And the Field Diary is a registration form of the participant observation in which all the impressions and feelings of the researcher are reported, any comments on the research subjects can be noted in this diary, while the researcher is in the field ${ }^{(14)}$.

\section{C) Information Production Process}

The research project was sent to the Brazil Platform under the CAAE number: 23953313.9.0000.5206 and approved by the Research Ethics Committee in 11/29/2013. For being a study with human, we set out the principles of prescriptive ethics and ethical dialogue, which involves the protection of anonymity, the guard of the abuse of power by the researcher and the Consent Form ${ }^{(15)}$. The latter was obtained by the participants' signature, the Consent Form $(\mathrm{CF})$, in which they agreed to participate in the study.

After an initial rapport, the researcher began the interview with the following question: How are you feeling? As they started talking, each subject expressed his/her way of experiencing palliative care. Given the need to further explore the topic, the researcher provoked the subject in a mild and careful way.

Everything that was observed during the entire period in which the researcher was close to participants, as well as their own emotions when hearing them, was recorded in a Field Diary. This record took place at the end of each observation period, to avoid interference in the field, and everything that could be perceived on the subject in palliative care was noted, as well as their relationship with the health team and with their families. The feelings of the researcher during the listening of subjects and observations in the field were also recorded. Impressions and interventions of the health team, which drew the attention of the researcher, were also noted.

\section{D) Information Analysis Process}

In order to understand the narrative of the subjects heard about their experiences on palliative care before a serious, chronic, progressive and degenerative illness, we used descriptive analysis inspired by Foucault. "Foucault's discourse analysis focuses on the availability of discursive resources within a culture - something like a discursive economy - and its implications for those who live in it"(9-112).

Foucault, with respect to discourse analysis, assumes that it is necessary to "reject the unambiguous explanations, easy interpretation and also the persistent pursuit of the ultimate meaning or the hidden meaning of thin$\mathrm{gs}^{\prime(16-189)}$. This means that what the subject means is already said in the discourse delivered by him/her, there are no questions to be revealed, there is nothing to be interpreted. In Foucault's perspective, when this is done in order to explain the position of the subject in front of a reality experienced by him/her, there is a decreased sense of his/ her experience due to the value given to science rather than his/her experience.

Discourse is constituted as the truth, as, in expressed words, we can notice history, culture, the principles of whom is producing the discourse, and it should not be disregarded when one wants to understand it. Still part of the discourse, we have the knowledge that allows it to exist as well, the place where it is being produced, who is being targeted and what is to achieve. Therefore, there is also a controlled action, a power system which produces discourse and, at the same time produced by them.

Every society of discourse production is simultaneously controlled, selected, organized and redistributed by certain numbers of procedures which are designed to conjure its powers and dangers, master their uncertain, dodge their heavy and fearsome materiality ${ }^{(10-8.9)}$.

Thus, the discourse is taken from a discursive field, discursive practices, it is built beyond the merely linguistic sphere, setting a limit to the social, because discourses are constructed in social relationships. In this study, the discursive field is palliative care, since it is the field of knowledge where the construction of the subject position circulates, the acting mode, the illness patient discourse. In the face of illness and the possibility of imminent death that he/she is dedicated to his/her conditions of possibilities to live this experience in one way or another.

\section{RESULTS}

The reports presented by the patients experiencing palliative care allow us to say that the choice for palliative care was given from not only the established clinical picture, but the moment of life of each individual, of their needs before what they were experiencing, their life expectancy and also the history of life that each one had.

\section{DISCUSSION}

Given any reality experienced, there are various possibilities to exist and to assume ways of being a subject. The finitude process is no different. Dying is a determination, but the way a subject experiences his/her finitude process is always singular, although it is crossed by the discourse of existing on a particular historical time. Thus, as the subjects in palliative care were listened and observed, the information produced was analyzed from three aspects: the meanings of palliative care before the impossibility of being cured, the choice for palliative care, and the impact of this choice. 


\section{A) The meanings of Palliative Care}

Palliative care, treatment aimed to comfort the discomforts of an illness, may be an update of possibilities, in front of the subject severe, chronic, progressive, degenerative ill state. To understand the meanings given to palliative care by ill individuals, it is essential to look at the context where these subjects are found. The moment of life they are in, future prospects they had for themselves, the repercussions of being sick, the possibilities involving both the treatment of the disease as palliative care, the existence of conditions that allow the patient undergoing palliative treatment to understand it on one way or another. Gustavo finds himself living with HIV/AIDS, additionally to a cancer in treatment. Therefore, he reports:

\begin{abstract}
Before knowing I had HIV, I was treating a tumor that appeared at the base of my penis... (crying). I did 15 sessions of chemotherapy, I went through a tough process of reactions that included vomiting, nausea, pain, hair loss, physical exhaustion ... So, now, the cancer is back, it is in the testicles and initially should be operated, but as it was presenting some changes in the skin, the doctor said that HIV testing would be necessary, but I did not expect it to be positive... So now, initially, I have to take care of AIDS, improve my immunity, improve my markers to use the drugs again and treat cancer... (the patient sighs) I will not do it all ... (crying) (crying).
\end{abstract}

Deciding for palliative care may be "the antithesis of all torture, of all violent deaths in which human beings are robbed not only for their lives but also their dignity"(17-291). In other words, when the patient does not invest in a treatment that cannot achieve a cure, it may make more sense to them as it allows less uncomfortable positions of being ill. It is in the construction process of the identity of being ill that the subject takes a position on the subject of what is imposed on him/her as an event.

The person who becomes seriously ill and for whom there is no cure perspective, is not just a patient, but a being of desires, wills, feelings that do not revolve only around the illness, but that constitute him/her as a being of possibilities. The palliative care may mean, for some, a way of experiencing a terminal illness, resisting a certain medical discourse that challenges to prolong life that is presented to them devoid of all modes of pleasure.

The meaning attributed to something, from a lived experience, is a one-way road, owned by who is going through that, only of those who instituted it. "The body is one of the sites involved in establishing the boundaries that define who we are, serving as a foundation for identity"(11-15). This identity is related to the historical and cultural context that through the symbols and meanings, produces subject positions $^{(11)}$, which were assumed to be the way the subjects' experiences their illness. It is as subjects of experience that the ill individual can choose the palliative treatment as a way to experience his/her illness. As this subject invests in his/her identity, not only his/her illness identity, but in all his/her life possibilities.

\section{B) The Choice For Palliative Care}

Palliation also involves a variety of sensations, which can, at the same time, hinder or facilitate decision making for palliate care. When the subject decides for palliative treatment, they "know" what led them to make that choice, but that does not make them insensitive to its impact. Opting for palliative care starts from the conditions of possibilities that the ill person is in the process of being ill. Ana is 80 years old, she has pancreatic cancer, and regarding the decision for palliative treatment she states:

Today I see that I made the best choice I could have
made. I got back to work, went out with my friends,
got rid of the treatment discomforts and feel no dis-
comfort because pancreatic cancer is painless, at least
I do not feel pain. According to my friends, I became
"thinner" because when I want something to drink,
wine is the least to danger my liver (laughs). So, I
started feeling better... My reflection had not consi-
dered the side of quality of life, but really, I have a
better life today than when I was treating my illness.
Ifeel lighter, happier.

Assuming palliative treatment as a way to deal with a serious illness is to take a position against being ill. It is considered in this process "the way that people think or feel (subjectivity), what they can do (practice) and the material conditions within such experiences can take pla$\mathrm{ce}^{\text {"(9-113) }}$. The choice for palliative care involves a set of occupations that can be understood as a care of the ill for himself/herself. In this care practice, the subject takes on a style to exist during illness.

Palliative treatment is difficult to be thought because it is usually related to the death of the ill subject. Faced with a diagnosis of a serious illness, the first action is contemplated treatment with therapeutic obstinacy, which may not prove effective. The ill person will then consider his/her ill condition and go on to look at the conditions likely to be ill, and these conditions are built from their history and culture. By understanding that this subject has possibilities, he/she can update them and deal with the illness in a more comfortable way and consistent with their feelings and the illness.

\section{C) Impacts of the Palliative Treatment}

Worrying about themselves, looking at themselves, taking care of themselves is to consider the whole context where they are and to experience an event. This involves looking at their own specific conditions of possibilities, which allows a subject a position on the construction of the patient identity. In the case of illness with no therapeutic possibilities of cure, the ill patient can assume a position of resistance to the family and doctor power, who tend to manage the therapeutic treatment persistently. Jorge has a brain tumor, he pointed out the difficulty of his family to understand his position.

I'm not well... I cannot stand all of this... It has been very difficult to make my family understand my choice. 
They want me to fight, to insist on treatment, but I don't want it... I know how it will end. When I found out the tumor, it was already grown and surgery could leave sequelae due to its location area ... I just want conscience and autonomy over what they will do with me, I think this is it. If you ask me if I want to die, the answer is "no, I do not want it" But between dying and vegetative state of life, I'd rather die.

The way of understanding the finiteness does not address only the subjectivity of the ill subject, but also their history, culture, the society around them, allows them to understand the terminality. In this sense, Foucault aimed to "create a history of the different ways in which, in our culture, human beings have become subjects"(18-231) and that means power relations by the fact that "while the human subject is placed in production relations and significance, he/she is also placed in very complex power relations" ${ }^{(18-232)}$. The discourses of the subjects do not relate solely to the action of speaking and writing, but also to the institutional practices of power, medicine and family are examples of such practices.

\section{CONCLUSION}

Finding out a severe, chronic, progressive and degenerative illness may allow the subject to experience frustration, anger, despair, sadness, feelings that increase when they are told about the impossibility of reversing the clinical picture, requiring them to experience their own finitude. The subject then can take it as an ill position from the patient's identity construction and at that time, offer resistance to a medical power that is imposed.

Being positioned as "a patient" within a biomedical discourse means that the body becomes a legitimate interest object to doctors and nurses, which may be exposed, touched and invaded in the treatment process which is part of the medical practice and their institutions (hospital, surgery) ${ }^{(9-113)}$.

Palliate care is to provide a treatment that allows the patient to undergo a physical and emotional well-being, before the impossibility of therapeutic cure. This feeling can be obtained at the time these people assume a position in the face of illness, not simply accepting the management of the ill and dying, by the health team. For this, the subject should be considered ill, also consider the possibilities that allow him/her to deal in one way or another with the experience of being ill.

Assuming a position before being ill allows the subject to experience the process of illness and death from the construction of an identity of being ill. That would be thinking about the possibilities of action that palliative care opens in terms of quality of life. It is worth noting that assuming a subject position, not necessarily means to be experiencing a free subjectivity of bonds. It is possible, in this movement, to reinforce roles, delimiting roles.

Regarding the term subject, there are two meanings. The first implies control and dependence; the second builds an identity through consciousness or self-awareness ${ }^{(18)}$. In this sense, the physician carries the power that his/her operations allow him/her to have. This categorization of subjects makes them subject to that identity. They become subjects of will to medical knowledge, requiring follow-up determinations. In return, the ill patient may assume an identity of being ill and, from there, take a subject position before his/her illness and finitude process.

The utterances presented of patients who experienced palliation bring the perception that the choice for palliative care was given from not only the clinical picture established, but also at the moment of life of each individual, of their needs given what they were experiencing, their life expectancy and also the history of life that each one had. And so they were constituted as subjects of their actions, updating their possibilities and considering the context that produced them from the production of their own discourses. With respect to patient subject and their way of being in the world, the following motto becomes valid: "Do not ask me who I am and do not tell me to stay the same"(19-20).

\title{
RESUMO
}

O presente trabalho traz uma reflexão a respeito do ser um doente terminal e das várias maneiras que o sujeito tem a seu dispor para lidar com esse acontecimento. Nosso objetivo foi compreender a experiência da paliação por sujeitos doentes sem possibilidades terapêuticas de cura. A metodologia deste estudo teve como instrumentos a Entrevista Narrativa, a Observação Participante e o Diário de Campo, sendo a Análise Descritiva de inspiração foucaultiana o modo como as narrativas dos sujeitos foram percebidas. O resultado do estudo mostrou a possibilidade de olhar a experiência do adoecer através da ótica de uma posição de sujeito assumida pelo próprio enfermo. E concluímos que ao escolher os cuidados paliativos, o doente terminal opta por um modo de se sentir mais confortável e resiste às imposições do modelo médico de prolongamento da vida.

\author{
DESCRITORES \\ Paliação, Adoecer, Finitude, Posição de Sujeito, Identidade.
}

\section{RESUMEN}

Este artículo presenta una reflexión acerca de ser un enfermo terminal y las diversas formas que el sujeto tiene a su disposición para hacer frente a este evento. Nuestro objetivo fue comprender la experiencia de pacientes sin posibilidad terapéuticas de cura, sometidos a los cuidados paliativos. La metodología de este estudio cuenta con los instrumentos de entrevista semiestructurada, la observación participante y el diario de campo. Las narrativas de los sujetos han sido analizadas bajo la analítica descriptiva de inspiración foucaultiana. Os Resultados nos dicen que la posibilidad de ver la experiencia de la enfermedad a través de la óptica de una posición de sujeto asumida por el propio enfermo. La conclusión es que es posible el sujeto enfermo terminal elegir los cuidados paliativos como una manera de sentirse más cómodo y para resistir a las imposiciones del modelo médico de la prolongación de la vida.

\section{DESCRIPTORES}

Paliación, Enfermo, La Finitud, Posición de Sujeto, de Identidad. 


\section{REFERENCES}

1. Ariès, P História da morte no ocidente. Rio de Janeiro. Ediouro. c2003

2. Foucault, M O nascimento da clínica. 7ed. Rio de Janeiro: Forense Universitária c2013.

3. Dantas, M M F A experiência da paliação: um olhar a partir do modo próprio de subjetivar-se diante do adoecer. Dissertação (mestrado) - Universidade Católica de Pernambuco c2014.

4. OMS Growing Older. Staying well. Ageing and Physical Activity in Everyday Life. Preparado por Heikkinen RL. Genebra: Organização Mundial da Saúde c. 1998.

5. Saunders, C Baines, M \& Dunloo, R Living with dying: a guide to paliative care. New York: Oxford University Press c1995.

6. Macieira, R C \& Palma, R R Psico-oncologia e cuidados paliativos In: Santos, F. S. cuidados paliativos: diretrizes humanização e alívio dos sintomas. São Paulo: HR Gráfica e Editora. c2002

7. Foucault, M História da sexualidade 2: o uso dos prazeres. Rio de Janeiro: Edições Graal c1984

8. Nicolazzi, F A narrativa da experiência em Foucault e Thompson. Anos 90, 11(19/20), JAN/DEZ c2004. 101-138 p.

9. Willing, C Análise de discurso foucaultiana. In: Introducing qualitative reserarch in psychology, 2nd edition, c2008, v. 07,112 - 113 p.

10. Foucault, M A ordem do discurso: aula inaugural no Cóllege de France, pronunciada em 2 de dezembro de 1970. $22^{a}$ ed. São Paulo: Edições Loyola c2012

11. Woodward, K Identidade e diferença: uma introdução teórica e conceitual. In: Silva, T. T da (Org.) Identidade e diferença: a perspectiva dos estudos culturais. Petrópolis, RJ: Vozes, c2000.

12. Fontella, B J B; Campos, C J G \& Turato, E R Coleta de dados na pesquisa clínico-qualitativa: uso de entrevistas não-dirigidas de questões abertas por profissionais de saúde. Revista Latino Americana de Enfermagem. Setembro-outubro c2006.

13. Queiroz D T, Vall J Souza A M A \& Vieira, N F C Observação participante na pesquisa qualitativa: conceitos e aplicações na área da saúde. Revista Enfermagem UERJ. Rio de Janeiro, abril/junho c2007.

14. Neves, V F A Pesquisa-ação e etnografia: caminhos cruzados. Revista Pesquisas e Práticas Psicossociais, São João Del-Rei, junho c2006, v. 1 , n. 1 .

15. Spink, M J A ética na perspectiva social: da perspectiva prescritiva à interanimação dialógica. Revista Semestral da Faculdade de Psicologia da PUCRS. v.31, n. 1, jun/jul c2000, $7-22$ p.

16. Fischer, R M B Foucault e a análise do discurso em educação. Cadernos de Pesquisa, n. 114, novembro c2001, 197 - 223 p.

17. Barchifontaine, C B A dignidade no processo de morrer IN Barchifontaine, C. B. \& Pessini, L. Bioética: alguns desafios. São Paulo: Edições Loyola c2002.

18. Foucault, M As palavras e as coisas, São Paulo: Martins fontes, c1995.

19. Foucault, M A arqueologia do saber. 7ed. Rio de Janeiro: Forense Universitária; c2008 